\title{
Investigating Speech Acts of Insult in the Speeches of Members of Provincial Assembly of Sindh, Pakistan
}

\author{
Shafqat Hussain \\ University of Sindh Jamshoro, Sindh, Pakistan \\ shafqat98hussain@gmail.com \\ Ameer Ali \\ University of Sindh, Jamshoro, Sindh, Pakistan \\ ameer7037@gmail.com* \\ Maya Khemlani David \\ University of Malaya, Kuala Lumpur, Malaysia \\ mayadavid@yahoo.com
}

\begin{abstract}
This study investigates speech acts of insult in speeches made by members of Provincial Assembly of Sindh, Pakistan using Austin's (1962) and Searle's (1969) Speech Acts Theory. This theory implies that language is used to perform acts, such as commanding, requesting, complaining, admiring, apologizing, insulting, and many others. However, in this research, researchers explore why speech acts of insult are performed by the members of Provincial Assembly of Sindh belonging to different political parties. Qualitative analysis of purposively sampled data collected from eleven participants' speeches, has been conducted to demonstrate how politicians enact speech acts of insult against each other. Findings reveal that the politicians performed speech acts of insult (expressive) when issues related to administration of Sindh and management of its resources (water distribution) were discussed. It is argued that members of the assembly are people's representatives, and they should behave in a civilized manner and perform civic, polite speech acts.
\end{abstract}

Keywords: Assembly, Expressive, Pakistan, Sindh, Speech Acts

\section{Introduction}

This study takes place against the background of increasing research on speech acts (David, 2016; Oloo, Ochieng \& Rew 2019; Hussain, Shahwar and Basit, 2020; Spago, Cumurija \& Maslo, 2019; David and Firdaus, 2021). A range of scholars have investigated how people perform acts through their language (Yarahmadi and Olfati, 2011; Dylgjeri, 2017; Simon and Cartis, 2014). Using the concepts defined in the speech act theory (Austin, 1962; Searle, 1969), this research views politicians' speeches in Provincial Assembly of Sindh as acts of insult and hatred. This research employs 'speech acts of hatred/insult' as a theoretical framework for conducting data analysis. Researchers (Shintia, 2020; Jucker and Taavitsainen, 2008) have already used this framework to show how the use of language can offend someone.

The idea of performing acts with language was defined and popularized by Austin (1962) and Searle (1969). The concept of speech acts has evolved over time. According to Ali and David (2021), in the wake of the COVID-19 pandemic, some people used language to perform acts of worship. Moreover, Agwuocha (2020) demonstrated how people performed acts of hatred and insult through social media platforms during COVID-19 induced lockdowns. Within this theoretical lens, this study seeks to explore 
how language has been used by politicians in the provincial assembly of Pakistan's Sindh province to insult or show hatred towards their political opponents.

In the context of this research, politicians' speech acts are conceptualized as manifestations of hatred and insult. Hence, speech acts of hatred and insult are seen at the heart of this analysis. We suggest that parliamentary language needs to be used by the politicians to save face of their opponents. Moreover, such laws need to be legislated as they will criminalize and penalize speech acts of hatred and insult both in formal and informal domains.

In the next section, local politicians' speeches, who are members of Provincial Assembly of Sindh, are contextualized against the political landscape of Pakistan's Sindh province.

\section{Contextualizing Politicians' Speeches within the Political Landscape of Pakistan's Sindh Province}

Sindh is a multilingual province in Pakistan where different language groups, such as the Sindhis, the Urdu-speaking community, the Seraikis, the Balochis, the Pashtuns, the Punjabis, and many others live (Ali and David, 2021); however, Sindhis are in majority in Sindh that is their native homeland (Ali and David, 2021). These diverse groups of languages are represented by different political parties in Sindh. There are four major political parties working in Sindh which are mentioned in Table 1.

Table 1: Major Political Parties in Sindh (Provincial Assembly of Sindh Website, 2021)

\begin{tabular}{|l|l|}
\hline \multicolumn{1}{|c|}{ Political Party Name } & No. of Seats in the Provincial Assembly \\
\hline Pakistan Peoples Party Parliamentarians & 99 \\
\hline Pakistan Tehreek-e-Insaaf & 30 \\
\hline Muttahida Quami Movement (Pakistan) & 21 \\
\hline Grand Democratic Alliance Pakistan & 14 \\
\hline
\end{tabular}

Pakistan Peoples Party (Parliament), which is currently governing Sindh province bagged highest seats in 2018 election in the province. In contrast, the last three parties in Table 1 are in alliance along with some other political parties forming opposition in the provincial assembly (source: Provincial Assembly of Sindh Website). The politicians belonging to government and opposition parties sometimes engage in derogatory speech acts which display their hatred and insult against each other. Therefore, we decided to investigate how acts of hatred and insult are enacted by politicians in their speeches in Provincial Assembly of Sindh using the theory of speech acts.

\section{Theoretical Framework: Speech Acts}

The concept of Speech Acts usually takes its place in both verbal and nonverbal communication (Hidayat, 2016). Speech act theory, according to Sadock (2006), demonstrates "the suitable balance between convention and intention" (p.53). Yule (1996) has described speech acts as a study of how listener and speaker utilize language. Moreover, Bach (1979) has stated that an action of verbal communication retains a message within it, and the communication normally does not only retain language, but also an action. According to Hidayat (2016), Birner has also postulated that utterance of an expression is basically doing of an action. Austin (1962), a linguistic theorist of Speech Acts, explains speech acts as actions performed by the production of utterances. Speech acts are further divided into three categories: Locutionary, Illocutionary and Perlocutionary (Hidayat, 2016).

\section{Austin's Concept:}

“......They do not 'describe' or 'report' or constate anything at all, are not 'true or false'; and the uttering of the sentence is, or is a part of, the doing of an action, which again would not normally be described as saying something" (Austin, 1962: p.6). 
Austin's statement implies that analysis of a speaker's meaning is central to Speech Act Theory. Saying is basically performing an act or in other words, the action comes from the utterances (Kloosterhuis, 2015). Austin divides utterances into performatives and constatives, then tries to come up with criteria for separating the two types of utterances (Araki, 2017).

The speech acts are divided into three categories: Locutionary, Illocutionary and Perlocutionary.

Locutionary: The act of Locutionary speech is basically equal to making a specific utterance with a particular sense and referent, which is pretty similar to meaning in the conventional sense (Austin, 1962). Simple utterance of a language like sound, phrases, etc., is an act of Locutionary speech act. It is considered as the physical act of speech (Renkama, 1993).

For Example: It is so hot in the room.

The above sentence shows the real condition of high temperature as described in the statement, and is just the utterance of the sentence.

Illocutionary: An utterance's communicative force, such as promising, apologizing, or offering, is used to perform the illocutionary act. This also suggests that the act of uttering something is basically performing an act. The illocutionary act is a prime level of an action in a speech act as it is determined by the force desired by the speakers (Hidayat, 2016: p.4).

For Example: It is so hot in the room.

The above example shows the request to switch on the fan or air condition.

Perlocutionary: When a speaker makes an utterance that has a specific effect on the listener and others, this is known as a perlocutionary act. In other words, the effect of an utterance on the other person's ideas or behavior is referred to as a perlocutionary act. (Hidayat, 2016, p.4)

For Example: It is so hot in the room.

On the basis of the above sentence, if a hearer goes to open a door or switches on a fan or air condition, it can be said that the statement has brought up its perlocutionary effect because an act has been performed.

Thus, speech acts can be also used by politicians in their speeches to target their opponents, and the communicating force of such speech acts offend a person's face (Kloosterhuis, 2015).

\section{Searle's Classified Illocutionary Act as Expressive:}

Searle (1969) classified five types of illocutionary act: Directive, Commissive, Declarative, Representative and Expressive. However, in this research, the speech act of expressive has been focused. The expressive speech acts can be performed using verbs such, regret, welcome, thank, abhor, appreciate, and deplore (Hussain, Shahwar \& Basit 2020).

The speech act of expressive can be used to express the feelings of hatred or insult, and according to Searle (1969), the act of insulting has some assertive qualities (its interactive session can often be assessed as true or false). He also postulates that it belongs more to the expressive category because it is more about expressing a speaker's psychological state (anger towards the addressee) than committing to the truth of the expressed proposition (Hussain, Shahwar \& Basit 2020; Syafi'i, 2014).

However, this study investigates speech acts of insult, focusing on the expressive illocutionary force, in the spoken discourses of members of the Provincial Assembly of Sindh, Pakistan. In this research, researchers explore how members of the Provincial Assembly of Sindh belonging to different political parties perform speech acts of insult. Qualitative analysis of purposively sampled data collected from politicians' speeches has been conducted to demonstrate how political discourse and party interests incite the assembly members to use speech acts of insult against their political opponents. The researchers inspect the statements made in the speeches with respect to the intended meaning and its impact on the listener and speaker, generating themes of insult and hatred. 


\section{Research Questions}

The study answers the following research questions

- Why are the speech acts of insult used by some members of Provincial Assembly of Sindh?

- How do some politicians enact speech acts of insult against their political opponents?

\section{Methodology}

In this study, qualitative method of data collection and analysis has been used. The content and form of the study remain qualitative. Data in the form of the speeches by the politicians are taken from the internet site, YouTube. The speeches were made by eleven politicians in the Provincial Assembly of Sindh and later uploaded to YouTube. The speech acts of insult relate to four key contextual situations which are given here.

- Discussion about division of Sindh

- Discussion about administrative issues of Karachi

- Diverging interests of the political parties

- Water issues in Sindh

The politicians whose speeches have been selected belong to four major political parties (see Table 2) in the house: Pakistan Peoples Party (Parliamentarians), Pakistan Tehreek-e-Insaaf (PTI), Muttahida Qaumi Movement Pakistan (MQM-P), and Grand Democratic Alliance (GDA).

There were eleven speeches, which included cross talks, selected to inspect and examine the speech acts of insult. The speeches were made in Urdu, Sindhi, and sometimes the speechmakers used codeswitching resulting in the alternative use of Urdu, Sindhi, and English. The speeches were played on YouTube and listened by the researchers, and these speeches were manually transcribed and translated into English. The relevant excerpts were further read and reread to identify general themes and patterns focusing on the speech acts of insult. The collected data were analyzed using Austin's (1962), and Searle's (1969) concepts of speech acts.

Table 2: Political Parties and Their Members

\begin{tabular}{|l|l|}
\hline Politicians & Their Political Party Name \\
\hline $\begin{array}{l}\text { Saeed Ghani, Sohail Anwar Siyal, Mukesh } \\
\text { Chawla, Sardar Ali Shah and Dr. Azra } \\
\text { Pechuho }\end{array}$ & Pakistan Peoples Party (Parliamentarians) \\
\hline $\begin{array}{l}\text { Khuram Sher Zaman, Ali Ji, Haleem Aadil } \\
\text { Shaikh and Abdul Ghaffar }\end{array}$ & Pakistan Tehreek-e-Insaaf \\
\hline $\begin{array}{l}\text { Firdos Shamim Naqvi } \\
\text { Nusrat Sahar Abbasi }\end{array}$ & Muttahida Qaumi Movement (P) \\
\hline
\end{tabular}

\section{Findings and Analysis}

This section includes the analysis of speech acts of insult enacted by some provincial ministers in Provincial Assembly of Sindh, Pakistan. The researchers have qualitatively interpreted the data using the theoretical framework of speech acts by Austin (1962) and Searle (1969).

The provincial assembly turns raucous when its members discuss or debate provincial issues. Sometimes, members of the assembly make personal, verbal attacks against their political opponents. The politicians' discourses demonstrate that speech acts of insult or hatred are enacted inside the provincial assembly. Members of different political parties, such as Pakistan Peoples Party 
(Parliamentarians), Pakistan Tehreek-e- Insaaf, Grand Democratic Alliance, Muttahida Qaumi Movement (Pakistan), and others are involved in the use of offensive, insulting speech acts.

The following list shows a number of reasons why politicians look down upon their opponents using speech acts of hatred.

- Personal rivalry

- Ethnic bias

- Ill-tempered nature

- Conflicting interests

- Political inclination (Degrading political image)

Now, we move on to examine speech acts of insult used by the politicians in their speeches made inside Provincial Assembly of Sindh. The four themes from the speech acts of insult are generated and analysed.

\section{Theme 1: Speech Acts of Insult in Relation to Administrative Issues of Sindh}

A provincial assembly member of Muttahida Qaumi Movement (Pakistan) made the following statement while indirectly criticizing and accusing the Pakistan Peoples Party-led government of conducting rigged election. The insulting speech acts are performed in relation to the administrative issues of Karachi that is provincial capital of Pakistan's Sindh province in the following utterance.

Urdu: "Me jilani sahab ko election me kamyabi par apni tamam opposition ki traf se mubarakbad pesh krta hon ........ wo bat dosri he k election fair tha ya nhe." (Naqvi, November 14, 2019)..

Translation in English: "On behalf of my all opposition members, I congratulate Mr. Jilani for winning the election...It is another case whether the election was fair or not" (Naqvi, November 14, 2019).

Firdos Shamim Naqvi is the leader of opposition belonging to Muttahida Qaumi Movement Pakistan that is in alliance with Pakistan Tehreek-e-Insaaf and Grand Democratic Alliance against Pakistan Peoples Party that is the ruling party in Provincial Assembly of Sindh, Pakistan. Naqvi's statement is an illocutionary speech act that casts aspersions against Pakistan Peoples Party because the politician implicitly claims that the party was involved in rigging of election. As Austin (1962) and Searle (1969) argued that saying is performing, Shamim is also performing acts of insulting his political opponents through speech. He goes on and uses speech act of expressives in his speech.

Urdu: "Aj me unko challenge krta hon $k$ Sindh k sar ka taj Karachi he, ayen mery halke me, (jo Karachi me he) mere sath, resign kren or jeet $k$ dikhaein, tb me manta hon, $k$ Sindh ki khidmat krny waly hein ye". (Shamim, 2019).

English Translation: "Today, I challenge them that Karachi which is considered as a crown of Sindh, let's come with me to my area (which is in Karachi), resign and fight the election there, and let's see who the winner is. Thus, I would agree and appreciate that you have served Sindh". (Naqvi, 2019)

Again, Naqvi uses the speech act of insult in Sindh Assembly, Pakistan by implicitly suggesting that election has been rigged. Shamim basically utters the ironic statements to humiliate the chief minister of Sindh, Murad Ali Shah. He challenges the chief minister to resign and recontest election from Naqvi's area against Naqvi. Naqvi enacts the speech act of insult by suggesting that the chief minister will neither resign nor contest the challenged election since people will not vote for him due to, he claims, the chief minister's lack of service and people friendly policies. The challenge from the opposition leader to the Chief Minister along with other accusations can be interpreted as an act of expressing negative attitudes towards the $\mathrm{CM}$. The tone of the speaker also sounded insulting as he performed the speech act in a belligerent way.

Naqvi, through such expressive statements is performing illocutionary act of insult against the leader of the house. Naqvi ironically asserts that the chief minister has not served the province of Sindh. If he had served, he must have shown this by taking up the gauntlet thrown by Naqvi. This actually 
displays the political interest of Naqvi's party to distort the image of the current ruling chief minister using insulting language. Such a tactic to score a political goal motivates Naqvi to produce these illocutionary expressive acts of hatred and insult.

The speech act of insult was also enacted another assembly minister, and this is now mentioned.

Sindhi: "Tu ker thidi ahen mhje ma baap lae ehryu galhion kandi, stupid woman?" (Dr. Pechuho, 2020).

English Translation: "How dare you make such comments about my parents, stupid woman!" (Dr. Pechuho, 2020).

Dr. Azra Fazal Pechuho, who is a health minister in the cabinet of Pakistan Peoples Party, Sindh, made the insulting remark against Nusrat Sehar Abbasi who is a provincial assembly member belonging to Grand Democratic Alliance. While addressing the assembly and providing the justification of the government's medical expenses and budget in Karachi, she uttered the pejorative phrase "stupid woman" in response to Nusrat Sehar Abbasi's comments about Pechuho's parents, which she claimed were unpleasant and unparliamentarily.

The use of such a pejorative terminology is an instance of perlocutionary force that comes about due to illocutionary act of insult or hatred. Abbasi was creating disturbance during the speech by giving the counter arguments without listening to Pechuho. She also argued something about the parents of Pechuho, but the voice did not sound clear. Thus, following the speech act and its illocutionary force of expressive, Pechuho could not control her hatred and anger and started insulting Abbasi. The insulting utterance by Dr. Pechuho was a personal attack against her. Abbasi also responded with the speech act insult.

Sindhi: "Aj jawab dio ta, aj jeko twha jo grand health jo alliance aa, oho press conference kre twha je munh te ahro tamacho hanyo aa..." (Abbasi, 2020).

English Translation: "In today's press conference, Grand Health Alliance has slapped on your face. Do you have any answer for it?" (Abbasi, 2020).

The above utterance is a speech act of insult enacted by Abbasi against Pechuho and her medical team. Abbasi, being a member of the opposition, performed an act of insult using a derogatory expressive, 'slap'. The statement displays the act of insult and hatred against Pechuho. She also implicitly conceptualizes the press conference as an act of slapping. She refers to a conference of Grand Health Alliance, in which issues, such as medical expenses that ensued in the wake of the COVID-19 pandemic were criticised. This reaction was basically a reply as a perlocutionary act to the insulting discourse used by Pechuho early in her speech, when she called Abbasi 'stupid'. Performing such insulting utterances against a woman by a woman shows how political party interests are prioritized.

In brief, the speech acts of insult enacted by the politicians related to the administrative issues, such as rigged election, lack of services, and health crises. Theme 2 that relates to speech acts resulting from diverging political interests is now presented and analyzed.

\section{Theme 2: Speech Acts of Insult in Relation to Diverging Interests of Politicians}

In response, members of Pakistan Peoples Party also used offensive language against the opposition members. For instance, a Pakistan Peoples Party member who currently serves as an education minister of Sindh made the following remark.

Urdu: Chief Minister shb to door ki bat hen, me inse kehta hon, ye resign kren apne seat se, me resign krta h apni seat, ye meri seat pr laren, me inki seat par larta hon. Himmat kren ye. (Ghani, 2019).

English Translation: "Not mention to the Chief Minister, I would suggest him let's resign from our seats, and I will contest election in his area, while he will contest election in my area. Come on show some courage!" (Ghani, 2019). 
In reply to Naqvi, the current Labour and Human Resources minister, Saeed Ghani stands up and starts his speech, which is a reaction to Naqvi's perlocutionary act of insult discussed under Theme 1. Ghani reacted to the insult to save the face and political image of the chief minister and his party (Pakistan Peoples Party Parliamentarians). He, in reaction, picks the gauntlet thrown down by Naqvi and pays back the same aspersions cast against the chief minister and his party. This expressive statement shows offence and insult against Naqvi. Much like Naqvi, Ghani also deploys speech acts of insult, however, the target of his speech performatives is the leader of the opposition who is Naqvi.

Additionally, Haleem Aadil Shaikh who is a member of opposition in Provincial Assembly of Sindh and belongs to Pakistan Tehreek-e-Insaaf made a statement that demonstrates an act of insult against the woman speaker of the assembly.

Urdu: "Apse permission le k bat nhe kreni mene, mene apni bat krni he" (Shaikh, 2021).

English Translation: "I do not need to seek your permission for speaking. I will speak out of my own free will" (Shaikh, 2021).

The above statement embodies offensive act performed by Shaikh. Shaikh uttered the statement in response to the Speaker of Provincial Assembly of Sindh. When the speaker asked him ("ap kia kehna chahte hein"? -What do you want to say?"), Shaikh did not save the speaker's face and replied in an insulting way. The statement was a two-pronged act of insult. First, he assumed such an insulting attitude towards a speaker who was a woman. Second, he displayed his arrogance by insultingly saying that he needs no permission of anyone. Thus, such a derogatory remark shows how a woman was mistreated, and how ethical codes of the assembly were also flouted. Thus, Shaikh broke the barriers of ethics, morality and respect for women. Therefore, it shows how male members of Provincial Assembly of Sindh insult their opponents, including the speaker of the assembly.

Urdu. "Sindh me kuto ka raj bht ziada ho gya he" (Zaman, 2021).

English Translation: "The rule of dogs has increased in Sindh" (Zamam, 2021).

Urdu: "Ary beth ja beth ja, udhr dhek udher bat kro, betho" (Chawla, 2021).

English Translation: "Oh, come on, sit, just sit down, speak and look there, sit down" (Chawla, 2021).

Khuram Sher Zaman, a member of Pakistan Tehreek-e-Insaaf, and Mukesh Chawla who belongs to Pakistan Peoples Party made the above given statements in Provincial Assembly of Sindh. The house raged with anger, hatred and insult. Zaman ironically referred to the incidents of dogs biting people and insultingly uttered that there is no rule by Pakistan Peoples Party rather dogs are ruling Sindh since they can freely bite any one they desire at any time. ${ }^{1}$ By the utterance, he indirectly called Pakistan Peoples Party leaders as dogs, because it's Pakistan Peoples Party who governs Sindh at the time. This utterance was beyond political and moral ethics.

In response to Zaman, Chawla also performed speech acts of insult. He could not bear the insult of his party, and in response, he insulted him by unusual and irritating expressions like, "sit down, just sit down, speak and look there". Such expressions irritate listeners. This performance of insult was also guided by conflicting political interests. His aim was to defend his party against the insulting speech acts. Thus, both the members of Provincial Assembly of Sindh humiliated one another with speech acts of insult. Zaman used expressive illocutionary to show his hatred and negative feelings, while Chawla enacted perlocutionary speech acts, as he aggressively ordered Zaman.

In this way, speech acts of insult were enacted by the politicians to preserve their diverging political interests by casting aspersions against their political opponents. Theme 3 that relates to the speech acts of insult in relation to Sindh's division is now presented and analyzed.

\footnotetext{
${ }^{1}$ Province of Sindh has been facing the problem of dogs biting children in streets and vaccines are not easily available.
} 


\section{Theme 3: Speech Act of Insult Used in Relation to Sindh's Division}

Saeed Ghani also aggressively spoke against the demand of dividing Sindh raised in the National Assembly of Pakistan with the assistance of Muttahida Qaumi Movement members. Ghani's speech act of insult is presented here.

Urdu: "Sindh k kitny hisy hone chahye, ye kisi k bap ki jageer nahe he!" (Ghani, 2019).

English Translation: "No one can dare divide Sindh, Sindh is not the land of anyone's forefathers!" (Ghani, 2019).

Ghani was discussing the issue of the partitioning of Sindh in Provincial Assembly of Sindh. He was much enraged when he performed the above speech act. The utterance is an example of the expressive illocutionary act because it dismisses the demand of separating Sindh. The minister insulted the opposition parties who secretly or openly called for the division of Sindh. His main argument was that no one could divide and change the map of Sindh. ${ }^{2}$ According to Ghani, Sindh (including Karachi) belongs to the Sindhi people. He aggressively asserted that the federal government has no constitutional right to divide Sindh. Thus, he angrily and insultingly spoke, although against such an unconstitutional demand.

Sardar Ali Shah who is, currently, the minister of Education Department in Sindh government cabinet also made a remark against the partition of Sindh. His words also perform the action of insulting against those who demand the separation of Karachi from Sindh. His speech act of insult is given here,

Urdu: "Constitution to kiya, agr asman se Sahifa bhi utar aye na, to be hm Sindh k partition ko qbol nh krengen!" (Shah, 2019) .

English Translation: "We will never accept the separation of Sindh at any cost, though the constitution of Pakistan or a religious scripture may recommend it". (Shah, 2019).

The above speech act is an illocutionary expressive act of insult because it directly rejects the demand of Sindh's separation, and no face-saving is given to the supporters of such a demand. He asserted that Sindh's separation will not be accepted at any cost. Therefore, it is an act of insult for the opposition parties preaching the partition because it aggressively rejects their demand of the partition of Sindh.

Speech acts of insult related to the issue of water scarcity in Sindh is now presented and analysed.

\section{Theme 4: Speech Acts of Insult in Relation to Water Scarcity Issue}

Speech acts with respect to scarcity of water in Sindh were also discussed and debated in Provincial Assembly of Sindh. However, some of the government and opposition members flouted parliamentary ethics and spoke insultingly against their political opponents. For instance, Pakistan Tehreek-e-Insaaf member, Ali Ji made the following remark against the ruling party members of the provincial assembly,

Urdu: "Jis qadar Sindh k andr pani he, Ap ki apni na laiqi he, apki chori he" (Ali Ji, 2021).

English Translation: "The scarcity of water in Sindh is your fault and your own theft" (Ali Ji, 2021).

The speech act of insult enacted in Ji' utterance reflects the political conflict of Pakistan Tehreek-eInsaaf with Pakistan Peoples Party. He accuses the ruling party ministers of stealing and misusing Sindh's water and calls them thieves of their own people. Such acts of speech are instances of illocutionary expressive force because these both express negative feelings and enact insult against political opponents. Every illocutionary act results in perlocutionary force (Austin, 1962), which in this

\footnotetext{
${ }^{2}$ Urdu speaking Muhajirs who are concentrated in Karachi demand that they should be given a separate province by carving Karachi and other areas out of Sindh (see Ali and David, 2021).
} 
case results in a harsh reaction when, Sohail Anwar Siyal, a member of Pakistan Peoples Party (Parliamentarians) made two following unparliamentarily comments which are given here.

Urdu: "Sindh ka pani jo chori krega us k ghron me hum ghusengen" (Siyal, 2021).

English Translation: "If you don't give the deserved water of Sindh, we would attack you in your homes" (Siyal, 2021)

Urdu: Aise jooty maregen, pani Sindh ka khaty ho or bakwaz krty ho" (Siyal, 2021).

English Translation: We will throw shoes at your face, you drink the water of Sindh, and speak rubbish against it" (Siyal, 2021).

Siyal is a current minister of irrigation in the cabinet of Pakistan Peoples Party in the Provincial Assembly of Sindh. He also performs the speech acts of insult while discussing the issue of water distribution in the house. ${ }^{3}$ He specifically performs these acts of insult against Pakistan Tehreek-eInsaaf's member Ali Ji. Such utterances of insult tarnish the image of assembly nationally and internationally, because these utterances amount to physical assaults. Though this issue can be talked politely and in a mannered way, but speech acts of insult were used to express anger and hatred. These speech acts of insult were used while the issue of shortage of water in Sindh was being discussed. Siyal's perlocutionary act of insult resulted in another harsh reaction from, a Pakistan Tehreek-e-Insaaf member, who enacted a personal verbal assualt,

Urdu: "Pars uthane ki wajah se wizarat mili he inko" (Ghafar, 2021).

English Translation: "He has got ministry so that he can carry purses (refers to a woman's purses who is an influential minister belonging to Pakistan Peoples Party Parliamentarians)." (Ghafar, 2021).

Ghafar's utterance is a personal verbal assault on Siyal, because he insultingly claims that Siyal has got ministry so that he can carry purses of the party chairman's aunt. These matters need not be discussed and brought to be discussed inside the assembly. The exchange of such personal verbal attacks shows how speech acts of insult are increasingly used inside the assembly in cogent debates and learned discussion of Sindh's issues.

\section{Discussion}

In Searle's (1969) words, expressive is a type of illocutionary act used to express feelings, emotions, and thoughts. Similarly, in this qualitative study, researchers have investigated how speech acts of expressive (insult) were used by the politicians inside the assembly. It was demonstrated that the politicians flouted the norms of politeness and enacted speech acts of insult when discussing the administrative issues, political interests, division of Sindh, water scarcity and other issues of Sindh.

Political interests, political rivalry, and ethnic motivations cause politicians to use the speech acts of insult against their opponents. In the words of Austin (1962), saying is the performance of the intended act. Similarly, the politicians also insult each other without considering the moral values. Unlike other researchers' findings (Hussain, Shahwar \& Basit, 2020) who studied representative and commissive speech acts in a political speech made by a Pakistani prime minister, this research focuses on the speech acts of Perlocutionary and illocutionary expressive (insult) used by the ministers of Provincial Assembly of Sindh.

\footnotetext{
${ }^{3}$ The issue of water distribution between the province of Sindh and the Punjab is very old one. Sindh, a lower riparian province, has contended that the Punjab, an upper riparian province, diverts water that Sindhi is die to get, which causes the agricultural damage in the lower districts of Sindh, such as Badin and Thatta. In contrast, the Punjab insists that this is actually the fault of the Sindh government that they do not distribute water equally in Sindh, which causes the water crisis. This latter stance was echoed by the opposition member inside the assembly.
} 
Findings of the study reveal the illocutionary force of speech act of insult (expressive) used by politicians who belong to four major political parties, Pakistan Peoples Party (Parliamentarians), Pakistan Tehreek-e-Insaaf (PTI), Muttahida Qaumi Movement Pakistan (MQM-P), and Grand Democratic Alliance (GDA). It was also demonstrated how the perlocutionary force was utilized to perform the act of insulting. This suggests that theoretical idea of Austin (1962) and Searle (1969), especially with respect to the speech act of insulting, is relevant in the context of Provincial Assembly of Sindh.

Unlike other researchers' findings (Spago, Cumurija \& Maslo, 2019) who showed how American president, Trump used tweets to enact speech acts of insult, this research demonstrated how and why politicians enact speech acts of insult in their provincial assembly speeches. Therefore, it is suggested that politicians should avoid the use of such unparliamentary language inside the assembly and focus on how to solve many issues facing Sindh and its people.

\section{Conclusion}

In short, politicians used speech acts of insult against their opponents inside Provincial Assembly of Sindh. The politicians belonging to four major parties of the assembly showed disrespect and insulted their opponents. It was shown how discussion related to administration and management of issues and resources diverged to hateful, personal attacks made using derogatory remarks. It is suggested that personal and political rivalries should be put aside and genuine issues of Sindh should be discussed in a polite manner leading towards a solution based discussion. This research used a small sample of speeches to study the speech acts of insult, however, a much bigger sample could be studied to arrive at the same findings. It is hoped that this research will help researchers in Pakistan and other contexts to study how and why politicians use speech acts of insult.

\section{References}

[1]. 24 News HD. (2020, June 4). YouTube. https://www.youtube.com/watch?v=uB8Pcgoo1E\&t=563s\&ab_channel=SAMAATVSAMAATVVerified

[2]. 24 News HD. (2021, April 22). YouTube. https://www.youtube.com/watch?v=zj9OFuP4muU

[3]. Abbasi, M. H. and David, M. (2021) "PANDEMIC, LAW, AND INDIGENOUS LANGUAGES IN PAKISTAN", IARS' International Research Journal. Vic. Australia, 11(1), pp. 10-16. doi: 10.51611/iars.irj.v11i1.2021.150.

[4]. Ali, A., \& David, M. K. (2021). A historical institutionalism approach to the politics of languages of Pakistan. Journal of Humanities and Social Sciences Research, 3(1), 75-90. https://doi.org/10.37534/bp.jhssr.2021.v3.n1.id1086.p75

[5]. ARAKI, N. (2018). Speech-Act Theory. Bull. Hiroshima Inst. Tech. Research, 52, 1-5.

[6]. ARY News. (2019, October 1). YouTube. https://www.youtube.com/watch?v=Q50EORyqAnU\&ab channel=ARYNewsARYNewsVerifie $\underline{\mathrm{d}}$

[7]. ARY News. (2021, February 26). YouTube. https://www.youtube.com/watch?v=zXoEoxI2Szw\&t=12s\&ab channel=ARYNewsARYNewsV erified

[8]. Austin, J. L. (1962). How To Do Things With Words (1st ed.). Oxford University Press, Amen House, London, E.C.q.

[9]. Bach, K. and R. M. Harnish. 1979. Linguistic Communication and Speech Acts, Cambridge, Mass: MIT Press.

[10]. David, M. K. (2016). Using Movies to teach the Speech Act of Refusals.

[11]. David, M. K., \& Azman Firdaus, A. N. (2021). Performing speech acts. Redefining the Role of Language in a Globalized World, 71-87. https://doi.org/10.4018/978-1-7998-28310. ch005

[12]. Dylgjeri, A. (2017). ANALYSIS OF SPEECH ACTS IN POLITICAL SPEECHES. European Journal of Social Sciences Studies, 2(2), 19-26. https://doi.org/ 10.5281/zenodo.344518 
[13]. Geo News. (2021, May 25). YouTube. https://www.youtube.com/watch?v=qLduRmTqstU

[14]. Hidayat, A. (2016). Speech Acts: Force behind Words. English Education: Jurnal Tadris Bahasa Inggris, 9(1), 1-12. http:ejournal.radenintan.ac.id/index.php/ENGEDU

[15]. Hussain, T., Shahwar, D., \& Basit, A. (2020). A Speech Act Analysis of the First Speech of Imran Khan as Prime Minister. Global Political Review, 5(2), 1-10. https://doi.org/10.31703/gpr.2020(V-II).01

[16]. Jucker, A. H., \& Taavitsainen, I. (2008). Speech acts in the history of English. John Benjamins Publishing.

[17]. Kloosterhuis, H. (2015). Insult in Context: Incorporating Speech Act Theory in Doctrinal Legal Analysis of Interpretative Discussions. ELR December, 3, 123-129. https://doi.org/ 10.5553/ELR.000054

[18]. Oloo, N. O., Dr. Ochieng, R. O., \& Prof. Rew, F. O. (2019). A Pragmatic Analysis of Speech Acts in Margaret Ogola's The River and the Source and I Swear by Apollo. European Journal of English Language, Linguistics and Literature, 6(1), 7-15. www.idpublications.org

[19]. Provincial Assembly of Sindh. (n.d.). Membership statistics. http://www.pas.gov.pk/index.php/members/stats/en/32. Retrieved July 15, 2021, from www.pas.gov.pk/index.php/members/stats/en/32

[20]. Renkema. (1993). Discourse Studies: An Introductory Textbook. Amsterdam: John Benjamin Publishing Company.

[21]. Sadock, J. (2006) "Speech Acts". In Horn, Laurence R. and Gregory Ward. The Handbook of Pragmatics. Blackwell Publishing LTd.

[22]. Searle, J. R. (1969). Speech acts: an essay in philosophy of language. London: CUP.

[23]. Shintia, G. (2020). A speech act analysis on direct speech in the book of Luke (NIV) [Master's thesis].

[24]. Simona,S and Cartis, D.D. (2015). Speech acts in written advertisements: Identification, Classification and analysis. procedia-social and behavioral sciences.192:234-239.

[25]. Singh, U. N. (2021) "AFTER THE DELUGE: AN ACTION NOTEBOOK FOR A RESPONSIBLE SOCIOLINGUIST", IARS' International Research Journal. Vic. Australia, 11(1), pp. 44-50. doi: 10.51611/iars.irj.v11i1.2021.155.

[26]. Spago, D., Cumurija, E. S., \& Maslo, A. (2019). Insults Speak Louder Than Words: Donald Trump's Tweets through the Lens of the Speech Act of Insulting. Journal of Language and Literary Studies, 139-159. DOI: 10.31902/fll.27.2019.9

[27]. TV SAMAA. $\quad$ (2019, January 30$). \quad$ YouTube. https://www.youtube.com/watch?v=mQEqejJoDTM\&t=86s\&ab channel=24NewsHD24New sHDVerified

[28]. TV SAMAA. (2021, May 25). https://www.youtube.com/watch?v=vJKJN2gkMlw\&ab channel=SAMAATV

[29]. TV SAMMA. (2019, May 1). pp mpa Sardar Ali Shah speach about sindh and mqm history in sindh assembly [Video]. Retrieved from https://www.youtube.com/watch?v=46nltFZppSg\&ab channel=Sindhline

[30]. TV SAMMA. (2021, May 25). Purse uthane ki waja se Wizarat mili hai - Sindh Assembly mein hungama - Samaa TV [Video]. Retrieved from https://www.youtube.com/watch?v=vJKJN2gkMlw\&t=14s\&ab channel=SAMAATV

[31]. Yarahmadi, M., \& Olfati, N. (2011). Speech Act Analysis of Anton Chekhov's The Seagull. Journal of Basic and Applied Scientific Research, 1(12), 2522-2527. www.textroad.com

[32]. Yule, G. 1996. Pragmatics. Oxford: Oxford University Press 


\begin{tabular}{|l|l|}
\hline \multicolumn{2}{|c|}{ Editorial Processing Record } \\
\hline Date of Submission: & $23-$ Oct-2021 \\
\hline Date of Final Review: & $29-$ Nov-2021 \\
\hline Date of Acceptance: & $02-$ Dec-2021 \\
\hline Final Processing: & $26-$ Dec-2021 \\
\hline Date of Publishing: & $29-$ Dec-2021 \\
\hline \multicolumn{2}{|c|}{ Last Plagiarism Report } \\
\hline \multicolumn{2}{|c|}{ Originality Assessment } \\
Overall Similarity: \\
Date: Dec 26, 2021 \\
Statistics: 398 words Plagiarized / 6026 Total words \\
Remarks: Low similarity detected, check your supervisor if changes are required \\
\hline
\end{tabular}

